\title{
Proinsulin and IGFBP-1 predicts mortality in an elderly population
}

\author{
Ioana Simona Chisalita, Ulf Dahlström, Hans Arnqvist and Urban Alehagen
}

\section{Linköping University Post Print}

N.B.: When citing this work, cite the original article.

Original Publication:

Ioana Simona Chisalita, Ulf Dahlström, Hans Arnqvist and Urban Alehagen, Proinsulin and IGFBP-1 predicts mortality in an elderly population, 2014, International Journal of Cardiology, (174), 2, 260-267.

http://dx.doi.org/10.1016/j.ijcard.2014.03.171

Copyright: Elsevier

http://www.elsevier.com/

Postprint available at: Linköping University Electronic Press

http://urn.kb.se/resolve?urn=urn:nbn:se:liu:diva-108157 


\title{
Proinsulin and IGFBP-1 predicts mortality in an elderly population
}

\author{
Simona I. Chisalita MD, PhD ${ }^{1}$, Ulf Dahlström MD, $\mathrm{PhD}^{2}$, \\ Hans J. Arnqvist MD, $\mathrm{PhD}^{3}$ and Urban Alehagen MD, $\mathrm{PhD}^{2}$
}

${ }^{1}$ Department of Acute Healthcare, County Council of Östergötland, Linköping, Cell Biology, Department of Clinical and Experimental Medicine, Faculty of Health Sciences, Linköping University, Sweden,

${ }^{2}$ Division of Cardiovascular Medicine, Department of Medicine and Health Sciences, Faculty of Health Sciences, Linköping University, Department of Cardiology UHL, County Council of Östergötland, Linköping, Sweden

${ }^{3}$ Cell Biology, Department of Clinical and Experimental Medicine, Faculty of Health Sciences, Linköping University, Department of Endocrinology and Gastroenterology UHL, County Council of Östergötland, Linköping, Sweden

Running title: Proinsulin and IGFBP-1 predictors of mortality

Statement of authorship: All authors (1-3) takes responsibility for all aspects of the reliability and freedom from bias of the data presented and their discussed interpretation

\section{Declaration of interest}

There is no conflict of interest that could be perceived as prejudicing the impartiality of the research report

\section{Funding}

This work was supported by the County Council of Östergötland (LIO-19611, 2009; LIO-19641, 2009; LIO-45751, 2009; LIO-131721, 2010; LIO-131411, 2010; LIO-60331, 2010). 
To whom correspondence should be addressed

\author{
Simona I. Chisalita \\ Department of Acute Healthcare \\ County Council of Östergötland, Linköping \\ S-581 85 Sweden \\ Telephone: + 460101030000 \\ Fax: +460101037077 \\ E-mail: ioana.simona.chisalita@liu.se
}

Word count: 3623 


\begin{abstract}
Background. High IGFBP-1 in elderly subjects is related to all-cause and cardiovascular (CV) mortality. We studied the relation of IGFBP-1 to cardiometabolic risk factors and cardiovascular and all-cause mortality, and also the impact of proinsulin and insulin on this association in an unselected elderly primary health care population.
\end{abstract}

Hypothesis. Our hypothesis was that proinsulin and insulin may have an impact on the association of high IGFBP-1 levels with all-cause and CV-mortality in elderly.

Design, Setting and Participants. Cross-sectional and prospective observational in a rural Swedish population. 851 persons aged 66-81 years, were evaluated by medical history, clinical examination, electrocardiography, echocardiography, and fasting plasma samples, and were followed prospectively for up to 12 years.

Results. At baseline, in a multivariate analysis, IGFBP-1 was associated with gender, N-terminal proBNP (NT pro-BNP), blood glucose, body mass index (BMI), insulin and proinsulin, estimated glomerular filtration rate (eGFR) and hemoglobin ( $\mathrm{Hb})$.

During the follow-up period there were 230 deaths (27\%), of which 134 (16\%) were due to CV mortality. When divided into tertiles there was a significant difference for CV mortality and allcause mortality between tertiles of IGFBP-1 and proinsulin. For insulin there was a significant difference only for all-cause mortality. After adjustment for well-known risks factors, proinsulin and IGFBP-1 had significant impact on all-cause mortality but only proinsulin on CV mortality. Conclusion. Only proinsulin is an independent predictor for both all-cause mortality and CV mortality when comparing IGFBP-1, insulin, and proinsulin as prognostic biomarkers for CV and all-cause mortality in an elderly population.

Keywords. Insulin-like growth factor binding protein-1, proinsulin, insulin, elderly population. 


\section{Introduction}

The insulin-like growth factors and insulin belong to a common ancient family having a structure highly preserved among vertebrate and invertebrate. IGF-I and insulin share an evolutionary precursor hormone (1). By binding 99\% of circulating IGF-I, IGFBPs act as a natural store, which prolongs IGF-I half-life and modulates its biological activity (2). Both low and high levels of circulating IGF-I have been reported to be associated with increased mortality (3-6), whereas high IGF-1 levels have been related with cancer mortality (7).

Insulin-like growth factor binding protein-1 (IGFBP-1) is produced in the liver and is negatively regulated by insulin (8). IGFBP-1 modulates the bioavailability of IGF-I by binding free IGF-I $(9,10)$. Low levels of IGFBP-1 are associated with insulin resistance and with the metabolic syndrome (11). Several cardiometabolic risk factors such as obesity, hyperinsulinemia, diabetes, hypertension and dyslipidemia are associated with IGFBP-1 (12-15). In elderly subjects, elevated IGFBP-1 levels have been reported to be related to chronic heart failure $(16,17)$, and all-cause and cardiovascular (CV) mortality (18-22). It has been shown that IGFBP-1 inhibits cancer cell growth and migration, and therefore low IGFBP-1 levels result in higher risk of cancer mortality (23). However data on IGFBP-1 levels and mortality are conflicting (18, 19, 21, 24-27).

Insulin is synthesized as pre-proinsulin, which is processed to proinsulin by removal of the signal peptide, and then further processed to mature insulin by prohormone convertases and carboxypeptidase (28). Secretory signals trigger the release of insulin and C-peptide in equimolar amounts together with small amounts of uncleaved proinsulin. Hyperinsulinemia has been reported to predict all-cause (29) and CV mortality $(30,31)$. Proinsulin is related to CV risk factors, such as dyslipidemia and hypertension, in diabetic and non-diabetic subjects $(32,33)$. Proinsulin concentration is more strongly correlated with CV risk factors than fasting or non- 
fasting insulin levels in both diabetic and non-diabetic subjects (34). Whether proinsulin has an impact on the association of IGFBP-1 in elderly subjects with overall and CV-related mortality is not known. High proinsulin levels have been associated with increased risk for cancer mortality (35). It has been speculated that this could be due to the different binding activity of proinsulin to the insulin receptors isoform A which could induce cell proliferation and migration (36).

Our hypothesis was that proinsulin and insulin may have an impact on the association of high IGFBP-1 levels with all-cause and CV-mortality in elderly. To test this hypothesis we studied the relation of IGFBP-1 as well as proinsulin and insulin to cardiometabolic risk factors and CV and total mortality in an unselected elderly population. 


\section{Research design and methods}

The study population has previously been described in detail (37). Briefly, all individuals aged 66 to 81 years residing in a south-eastern Swedish rural municipality with a population of 10,300 were chosen. Of 1162 eligible subjects, 851 (73.3\%) agreed to participate and give blood samples that are analysed in this evaluation.

All participants (851 persons) were examined by one of three experienced cardiologists. A medical history was taken, and a clinical examination, including weight and height, was performed. An electrocardiogram and Doppler echocardiography were obtained. The New York Heart Association functional class (NYHA Class) was assessed. Blood pressure was measured to the nearest $5 \mathrm{~mm} \mathrm{Hg}$, with the patient resting in a supine position. The study protocol was approved by the Ethics Review Board in Linköping.

\section{Blood samples and biochemical analysis}

Blood samples were obtained at baseline from fasting subjects after a resting period of 30 minutes. The samples were collected in pre-chilled plastic tubes containing EDTA (Terumo EDTA K-3), placed on ice, and centrifuged at $3000 \mathrm{~g}$ for 10 minutes at $4{ }^{\circ} \mathrm{C}$, and then immediately stored at $-70^{\circ} \mathrm{C}$ pending analysis. Total plasma IGFBP-1 was measured by a one-step enzymelinked immunosorbent assay (ELISA) with a commercial kit (R\&D Systems, Minneapolis, MN, USA). At our lab, interassay coefficients of variation (CV) for high (1688 $\mu \mathrm{g} / \mathrm{L})$ and low (4 $\mu \mathrm{g} / \mathrm{L})$ controls were $7.8 \%$ and $20.0 \%$ respectively. Total IGF1 was measured by a one-step ELISA after acid-ethanol extraction from its binding protein using a commercial kit (Human IGF-I Quantikine ELISA Kit R\&D Systems, Minneapolis, MN, USA). Interassay coefficients of variation were $10.9,5.9$, and $18.2 \%$ for high $(278 \mu \mathrm{g} / \mathrm{L})$, medium $(116 \mu \mathrm{g} / \mathrm{L})$, and low $(45 \mu \mathrm{g} / \mathrm{L})$ controls respectively. Insulin and proinsulin concentrations were measured by a one-step 
enzyme-linked immunosorbent assay (ELISA) with a commercial kit (DAKO, Glostrup,

Denmark). N-terminal proBNP (NT-proBNP) was measured using an electrochemiluminescence immunoassay (Elecsys 2010, Roche Diagnostics, Mannheim, Germany), first described by Karl (38). The analytical range was 5 to $35,000 \mathrm{ng} / \mathrm{L}(0.6$ to $4130 \mathrm{pmol} / \mathrm{L})$. The total coefficient of variation was $4.8 \%$ at the level of $217 \mathrm{ng} / \mathrm{L}(26 \mathrm{pmol} / \mathrm{L})(\mathrm{n}=70)$ and $2.1 \%$ at the level of 4261 $\mathrm{ng} / \mathrm{L}(503 \mathrm{pmol} / \mathrm{L})$ at our laboratory.

Estimated glomerular filtration rate (eGFR) was calculated by use of the Cockcroft-Gault formula (39).

\section{Doppler echocardiography}

Doppler echocardiography (Accuson XP-128c) was performed on all patients in the left supine position. Both M-mode and two-dimensional methodologies were used. The left ventricular systolic function was determined semi-quantitatively, with the global systolic function classified

as follows: normal (ejection fraction $[\mathrm{EF}] \geq 50 \%$ ); mild impairment (EF $40 \%$ to $49 \%$ ); moderately impaired function (EF 30\% to 40\%); and severely impaired function (EF $<30 \%$ ). The method has been validated against the modified Simpson algorithm (40-41).

\section{Concomitant diseases}

Diabetes mellitus (DM) was defined as a fasting plasma blood glucose concentration $\geq 7.0$ $\mathrm{mmol} / \mathrm{L}$, or current treatment for diabetes (diet, oral therapy or insulin). Ischemic heart disease (IHD) was defined as a history of coronary artery disease (CAD), angina pectoris, treatment for angina pectoris, a previously verified myocardial infarction, coronary artery bypass surgery, percutaneous coronary intervention, and/or ECG changes characteristic of IHD (evaluated by three experienced cardiologists).

\section{Follow-up of included patients}


All patients were followed-up for 12 years $(7.9 \pm 2.6)($ mean $\pm \mathrm{SD})$ and no patient was lost during this period. During the follow-up period all patients received standard treatment according to clinical routines.

When patients were reported to have died, death certificates were obtained from the Swedish Central Population Registry and information about cause of death and/or autopsy reports, if available, were analysed by the authors. All autopsies were performed at the University Hospital in Linköping. All-cause mortality and CV mortality were chosen as end points. CV mortality was defined as death caused by HF (heart failure), fatal arrhythmia, sudden death, IHD, or cerebrovascular death as deduced from the autopsy report or death certificate issued by the physician in charge of the patient.

\section{Statistics}

For normally distributed variables, data are presented as mean \pm SD. Patients were stratified into tertiles of IGFBP-1, insulin, proinsulin, and NT-proBNP. The differences between tertiles 1-3 of IGFBP-1 with regard to the characteristics of the studied population were analysed by ANOVA using Bonferroni as post hoc analysis. As IGFBP-1, insulin, proinsulin, and NT-proBNP concentrations were skewly distributed, they were all ${ }^{10} \log$ transformed to normal distribution. Differences in distribution of patients with diabetes mellitus between tertiles 1-3 of IGFBP-1 were analysed by Chi-square test. The association between IGFBP-1 and cardiometabolic risk factors was analysed by Spearman's correlation test and also by multivariate regression. HOMAIR (Homeostasis Model of Assessment - Insulin Resistance) as a marker of insulin resistance was calculated (fasting Glucose(mg/dl) x fasting Insulin $(\mu \mathrm{U} / \mathrm{mL}) / 405)$.

Cox proportional hazard regression analyses were used to analyse the risk of both all-cause and $\mathrm{CV}$ mortality during the total follow-up period. A multivariate Cox proportional hazard 
regression analysis was used to assess the impact of gender, age $>75$ years, $\mathrm{Hb}<120 \mathrm{~g} / \mathrm{L}, \mathrm{DM}$, IHD, $\mathrm{EF}<40 \%$, eGFR $<60 \mathrm{~mL} / \mathrm{min}$ and tertiles of NT pro-BNP, IGFBP-1, insulin, and proinsulin levels. Survival analysis was made using Kaplan-Meier survival curve analysis. A p-value less than 0.05 was considered statistically significant. Data analysis was performed using the commercially available statistical analysis software package IBM SPSS statistic version 20 (SPSS Inc. Headquarters, Chicago, Illinois, USA). 


\section{Results}

\section{IGFBP-1 levels and characteristics of the study population}

To analyse the characteristics of the study population in relation to IGFBP-1, tertiles of IGFBP-1 were used (Table 1a). When tested by ANOVA there were highly significant differences $(\mathrm{p}<0.001)$ between tertiles of IGFBP-1 for age, eGFR $<60, \mathrm{Hb}$, BMI and cardiometabolic risk factors: ${ }^{10} \log$ proinsulin, ${ }^{10} \log$ insulin, triglycerides and also ${ }^{10} \log$ NT pro-BNP. Significant differences were also found for blood glucose $(\mathrm{p}<0.05)$ and $\mathrm{DM}(\mathrm{p}<0.02)$. Insulin $(\mathrm{r}=-0.24$, $\mathrm{p}<0.001)$ and proinsulin $(\mathrm{r}=-0.17, \mathrm{p}<0.001)$ were negatively and highly significantly correlated to IGFBP-1 levels. We found a positive correlation between levels of CRP and HOMA ( $\mathrm{r}=0.16$, $\mathrm{p}<0.001)$, and a tendency to correlation between levels of IGFBP-1 and HOMA ( $\mathrm{r}=0.07$, $\mathrm{p}=0.053)$.

When tested by ANOVA using Bonferroni as post hoc analysis there were differences $(p<0.001)$ between tertile 1 compared to tertile 3 of IGFBP-1 for age, BMI, triglycerides, ${ }^{10} \log$ insulin, ${ }^{10} \log$, proinsulin,,${ }^{10} \log$ NT-proBNP, eGFR and Hb (Table 1b). Significant differences between tertile 1 to 2 and/or 2 to 3 were found for age, BMI, triglycerides, ${ }^{10} \log$ proinsulin, ${ }^{10} \log$ insulin, ${ }^{10} \log$ NT-proBNP, eGFR, and $\mathrm{Hb}$, respectively (Table 1b). Using a Chi-square test, no significant differences in distribution of patients with DM between tertiles 1-3 of IGFBP-1 were found. In multivariate regression analysis with ${ }^{10} \log$ IGFBP-1 as a dependent variable and age, gender, BMI, DM, blood glucose, Hb, eGFR,,${ }^{10} \log$, proinsulin, ${ }^{10} \log$ insulin, ${ }^{10} \log$ NT-proBNP, BT systolic and triglyceride as independent variables. Gender ( $<<0.001)$, BMI, $(\mathrm{p}=0.02)$, blood glucose $\left((\mathrm{p}<0.001), \mathrm{Hb}(\mathrm{p}<0.001)\right.$, GFR $(\mathrm{p}<0.001),{ }^{10} \log$ proinsulin $(\mathrm{p}=0.002),{ }^{10} \log$ insulin $(\mathrm{p}=0.003)$ and ${ }^{10} \log$ NT-proBNP $(\mathrm{p}<0.001)$ had a significant impact. In order to eliminate the impact of age on changes in hormonal and others variables with age, we analysed each of them as dependent 
variables in a univariate analysis with tertiles of IGFBP-1 as fixed variables and age as a covariable. The result show that the significant differences between tertile 1 to 3 IGFBP-1 are still available when adjusted for age for BMI ( $\mathrm{p}<0.001), \mathrm{Hb}(\mathrm{p}<0.001), \mathrm{GFR}(\mathrm{p}<0.001),{ }^{10} \log$ proinsulin $(\mathrm{p}<0.001),{ }^{10} \log$ insulin $(\mathrm{p}<0.001)$ and ${ }^{10} \log$ NT-proBNP $(\mathrm{p}<0.001)$, but not for blood glucose (NS). With regard to DM by using a logistic regression with DM as dependent variable and tertiles of IGFBP-1 and age as co-variables a significant difference was shown between tertile 1 to $3(p=0.04)$ and 1 to $2(p=0.006)$.

\section{CV mortality and all-cause mortality in relation to tertiles of IGFBP-1, insulin, and proinsulin}

The study population was followed for up to 12 years $(7.9 \pm 2.6)$. During the follow-up period there were 230 deaths (27\%) of which $134(16 \%)$ were due to CV mortality. For all-cause and CV mortality incidence rate/10,000 person/ years were 323 and 134, respectively. For IGFBP-1, CV mortality and all-cause mortality increased with a linear trend with increased tertiles 1-3. For proinsulin, and insulin, a U-shaped trend was found, with lower values in tertile 2 (Figure 1, Table 2).

\section{IGFBP-1, insulin, and proinsulin as prognostic biomarkers for all-cause mortality}

In order to assess the prognostic potential of IGFBP-1, insulin, and proinsulin for all-cause mortality, univariate Cox proportional hazard regression analyses were used (Table 3a) during the whole follow-up period. The risk for all-cause mortality was higher for participants with plasma IGFBP-1 and proinsulin concentrations in the $3^{\text {rd }}$ tertiles compared to those in the $1^{\text {st }}$ tertile 
(Table 3a). A multivariate Cox proportional hazard regression analysis was then performed using a model including well-known variables for CV mortality (Table 3b) and tertiles of IGFBP-1, insulin and proinsulin. Also in the multivariate analysis the risk for all-cause mortality was higher for participants with plasma IGFBP-1 and proinsulin concentrations in the $3^{\text {rd }}$ tertiles compared to those in the $1^{\text {st }}$ tertile. When tertiles of IGF-1/IGFBP-1 ratio was introduced instead of IGFBP1 tertiles in Cox proportional hazard regression analysis, similar results were obtained (data not shown).

\section{IGFBP-1, insulin and, proinsulin as prognostic biomarkers for CV mortality}

In order to assess the prognostic potential of IGFBP-1, insulin, and proinsulin for CV mortality, univariate Cox proportional analysis was used (Table 3a) during the follow-up period. For the whole period, the risk for CV mortality was lower for participants with plasma IGFBP-1 and proinsulin concentrations in the $1^{\text {st }}$ tertile compared to those in the $3^{\text {rd }}$ tertile (Table $3 \mathrm{a}$ ). For proinsulin the opposite result was obtained when the $1^{\text {st }}$ tertile was compared to the $2^{\text {nd }}$ tertile indicating a U-shaped relation. In the univariate analysis we found no association between insulin and CV mortality (Table 3a).

A multivariate Cox proportional hazard regression analysis was then performed using a model including other well-known variables for CV mortality (Table 3b) and tertiles of IGFBP-1, insulin and proinsulin. When the $1^{\text {st }}$ tertile was compared to the $2^{\text {nd }}$ and $3^{\text {rd }}$ tertile there were no significant effects. However, there was a significant difference between the proinsulin tertiles (p $=0.005)$ but not the other tertiles and the hazard ratio when comparing the $2^{\text {nd }}$ to the $3^{\text {rd }}$ tertile of proinsulin was 0.5 with a CI of $0.3-0.7(\mathrm{p}<0.001)$. The results show that only proinsulin had a significant impact on CV mortality for the whole period. 
When tertiles of IGF-1/IGFBP-1 ratio was introduced instead of IGFBP-1 tertiles in Cox proportional hazard regression analysis, similar results were obtained.

IGFBP-1, insulin and, proinsulin as prognostic biomarkers for cancer mortality

In our study individuals with fasting proinsulin levels $>11.7 \mathrm{pmol} / \mathrm{L}$ (tertile3) had a 3-fold risk of cancer mortality compared to tertile 1 up to 12 years of follow-up $(p=0.016)$, whereas there were no significant differences between tertiles of insulin or IGFBP-1. When tertiles of IGF-1/IGFBP1 ratio was introduced instead of IGFBP-1 tertiles in Cox proportional hazard regression analysis, similar results were obtained. 


\section{Discussion}

In this study, which compared IGFBP-1, insulin, and proinsulin as prognostic biomarkers for CV and all-cause mortality followed up to 12 years, we found that after adjustment for well-known $\mathrm{CV}$ risk factors, only proinsulin was an independent predictor for both all-cause mortality and CV mortality. To our knowledge, this is the only study which has investigated the prognostic impact of IGFBP-1, insulin, and proinsulin concomitantly on CV and all-cause mortality in an unselected elderly population with concomitant diseases representative for their age. A new observation shown here is also the negative association between IGFBP-1 and proinsulin.

\section{Cardiometabolic risk factor}

Metabolic syndrome includes disturbances in glucose metabolism, insulin resistance, overweight, dyslipidemia and hypertension $(42,43)$. In this study we found that IGFBP-1 inversely correlated with BMI, triglycerides and diastolic BP, which was consistently found in previous studies (13, $15,19,21,44)$. Our results showed that blood glucose was positively correlated to IGFBP-1 levels, as was also reported by Kajante and $\mathrm{Hu}(13,21)$, whereas in other studies an inverse correlation was found $(15,19)$. It is well known that IGFBP-1 is down-regulated by insulin, and as expected, we found a negative correlation between IGFBP-1 and insulin levels $(19,44,45)$. It is possible that the different results for blood glucose reflect different states of insulin resistance in the studied populations (44). There was a negative and highly significant correlation between IGFBP-1 and proinsulin. To our knowledge, the association between IGFBP-1 and proinsulin has not been studied before. 


\section{Impact of insulin and proinsulin on mortality}

In multivariate analysis, only proinsulin was an independent risk factor for all-cause and $\mathrm{CV}$ mortality. Our findings are similar to the results obtained in the Hoorn study (46), in which proinsulin but not insulin was found to be an independent risk factor for all-cause and CV mortality after adjustment for age and sex. Studying CV mortality, Zethelius et al. (34) found in a 27-year follow-up study of a male population that insulin and proinsulin at baseline in univariate analysis were risk factors, whereas in multivariate analysis, only proinsulin was an independent risk factor. An association of elevated proinsulin with atherosclerosis or CV diseases has also been reported by other groups $(32,33)$.

\section{IGFBP-1 and mortality}

In an univariate Cox regression we found that IGFBP-1 was a risk factor for all-cause mortality and CV mortality during the follow-up period. In studies restricted to older men with an average follow-up of five years, similar results were reported by Yeap et al. (15) and Harrela et al. (18). In a multivariate Cox regression we found a significant prognostic outcome of IGFBP-1 on allcause mortality but not on CV-mortality in contrast to Yeap et al. (15) and Harrela et al. (18) who also found an association with CV mortality. When only analysing the association between high IGFBP-1 levels and all-cause mortality, Kaplan et al. (20) and Hu et al. (21) found that high IGFBP-1 predicted mortality. A probable explanation for the discrepant results in the multivariate analysis is the fact that different risk factors were used for adjustment. In our multivariate model, NT-proBNP was a very strong risk indicator, which was not taken into consideration in previous studies addressing the association between IGFBP-1 and mortality. 


\section{Proinsulin as an independent predictor factor for both all-cause mortality and CV mortality and cancer mortality}

In our study results from the multivariate analysis show that only proinsulin was an independent risk factor for all-cause, $\mathrm{CV}$ and cancer mortality. As we mention above our findings are in concordance with previous results reported in the Hoorn study (46) and by Zethelius et al. (34), where in the multivariate analyses proinsulin was found to be an independent risk factor for allcause and CV mortality after adjustment. In our study we take into consideration besides proinsulin and insulin, IGFBP-1 which has not been done before, and found that proinsulin of all 3 hormones has a great importance as an independent prognostic risk factor for mortality. The association between high proinsulin and increased mortality may be explained by high proinsulin reflecting a process that has an impact on mortality or by proinsulin having a direct biologic effect that is negative. Beta-cell stress is associated with an increased proinsulin secretion (47). Insulin resistance is a cause of beta-cell stress and is also associated with increased mortality (48). It is therefore conceivable that high proinsulin is a marker of insulin resistance. Proinsulin binds with very low affinity to the insulin receptor and there is no specific receptor for proinsulin (49). Whether proinsulin or its split products have direct effects of their own is controversial.

\section{IGFBP-1, insulin and, proinsulin as prognostic biomarkers for cancer mortality}

In our study individuals with fasting proinsulin levels $>11.7$ (tertile3) have a 3-fold risk of cancer mortality compared to tertile 1 up to 12 years of follow-up. Data are in accordance with a recent publication by Walraven et al. (35). The mechanism behind this association could possibly be explained by the different binding activity of proinsulin to the two insulin receptors (IR) isoform A and B (36). Malaguarnera et al. have shown that proinsulin is a selective IR-A ligand by 
having an almost equipotent to insulin effect on cell proliferation and migration in cells expressing IR-A (36).

It has been suggested that the ratio of IGF-1 to IGFBP-1, the IGF/IGFBP-1 ratio probably represents a more reliable marker of IGF-1 bioactivity and a more powerful indicator of adverse outcomes than IGF-1 and IGFBP (14). When tertiles of IGF-1/IGFBP-1 ratio was introduced instead of IGFBP-1 tertiles in the Cox proportional hazard regression analysis in our study, similar results were obtained for $\mathrm{CV}$, all-cause and cancer mortality.

The main strength of the present population is that the participants were recruited directly from the community without sampling, and every participant was followed over a long period of time, up to 12 years $(7.9 \pm 2.6)$. No patient was lost during follow-up. Nevertheless, this study has some limitations. The analysis of hormones and other biochemistry was only done at baseline. This is an observational study, which is why conclusions about the causal role of proinsulin on mortality can only be speculative. Another limitation is the limited age span of study participants (66 to 81 years), which makes extrapolation of the results to other age groups unwise.

\section{Conclusion}

When comparing IGFBP-1, insulin, and proinsulin as prognostic biomarkers for CV and all-cause mortality in an elderly population we found only proinsulin to be an independent predictor for both all-cause mortality and CV mortality. Our results suggest that proinsulin is an important prognostic biomarker even in an elderly population, and highlight the importance of proinsulin not only as a cardiometabolic risk factor, but also as a biomarker for CV mortality. We consider that this unique biomarker, proinsulin, is a candidate for development of a prognostic panel of biomarkers for all-cause and CV mortality. 


\section{Acknowledgements}

We are grateful to Anna-Kristina Granath for her excellent technical assistance. 


\section{References}

1. Blundell TL, Humbel RE. Hormone families: pancreatic hormones and homologous growth factors. Nature 1980;287(5785):781-7.

2. Ekins R. The free hormone hypothesis and measurement of free hormones. Clin Chem. 1992; 38(7):1289-93.

3. Chisalita SI, Dahlström U, Arnqvist HJ, Alehagen U. Increased IGF1 levels in relation to heart failure and cardiovascular mortality in an elderly population: impact of ACE inhibitors. Eur J Endocrinol. 2011;165(6):891-8

4. Bunderen CC, van Nieuwpoort IC, van Schoor NM, Deeg DJ, Lips P, Drent ML. The association of serum insulin-like growth factor-I with mortality, cardiovascular disease, and cancer in the elderly: a population-based study. J Clin Endocrinol Metab. 2010;95(10):4616-2

5. Fischer F, Schulte H, Mohan S, Tataru MC, Köhler E, Assmann G, von Eckardstein A. Associations of insulin-like growth factors, insulin-like growth factor binding proteins and acid-labile subunit with coronary heart disease. Clin Endocrinol (Oxf). 2004;61(5):595-602

6. Andreassen M, Raymond I, Kistorp C, Hildebrandt P, Faber J, Kristensen LØ. IGF-1 as predictor of all cause mortality and cardiovascular disease in an elderly population. Eur J Endocrinol. 2009;160(1):25-31

7. Maggio M, Cattabiani C, Lauretani F, Bandinelli S, De Vita F, Dall'aglio E, Corsonello A, Lattanzio F, Paolisso G, Ferrucci L, Ceda GP. Insulin-like growth factor-1 bioactivity plays a prosurvival role in older participants. J Gerontol A Biol Sci Med Sci. 2013;68(11):1342-50

8. Brismar K, Fernqvist-Forbes E, Wahren J, Hall K. Effect of insulin on the hepatic production of insulin-like growth factor-binding protein-1 (IGFBP-1), IGFBP-3, and IGF-I in insulin-dependent diabetes. J Clin Endocrinol Metab. 1994;79:872-878

9. Rosen CJ. Serum insulin-like growth factors and insulin-like growth factor-binding proteins: clinical implications. Clinical Chemistry 1999;45: 1384-1390

10. Firth SM, Baxter RC. Cellular actions of the insulin-like growth factor binding proteins. Endocrine Reviews 2002;23:824-854

11. Maddux BA, Chan A, De Filippis EA, Mandarino LJ, Goldfine ID. IGF-binding protein-1 levels are related to insulin-mediated glucose disposal and are a potential serum marker of insulin resistance. Diabetes Care 2006;29:1535-1537

12. Janssen JA, Stolk RP, Pols HA, Grobbee DE, Lamberts SW. Serum total IGF-I, free IGF-I, and IGFB-1 levels in an elderly population: relation to cardiovascular risk factors and disease. Arterioscler Thromb Vasc Biol. 1998;18:277-282

13. Kajantie E, Fall CH, Seppälä M, Koistinen R, Dunkel L, Ylihärsilä H, Osmond C, Andersson S, Barker DJ, Forsén T, Holt RI, Phillips DI, Eriksson J. Serum insulin-like growth factor (IGF)-I and IGF-binding protein-1 in elderly people: relationships with cardiovascular risk factors, body composition, size at birth, and childhood growth. J Clin Endocrinol Metab. 2003;88:1059-1065 
14. Boquist S, Ruotolo G, Skoglund-Andersson C, Tang R, Björkegren J, Bond MG, de Faire U, Brismar K, Hamsten A. Correlation of serum IGF-I and IGFBP-1 and -3 to cardiovascular risk indicators and early carotid atherosclerosis in healthy middle-aged men. Clin Endocrinol (Oxf). 2008; 68: 51-58

15. Yeap BB, Chubb SA, Ho KK, Setoh JW, McCaul KA, Norman PE, Jamrozik K, Flicker L. IGF1 and its binding proteins 3 and 1 are differentially associated with metabolic syndrome in older men. Eur J Endocrinol. 2010;162:249-257

16. Kaplan RC, McGinn AP, Pollak MN, Kuller L, Strickler HD, Rohan TE, Cappola AR, Xue X, Psaty BM. High insulin-like growth factor binding protein 1 level predicts incident congestive heart failure in the elderly. Am Heart J. 2008;155: 1006-1012

17. Janszky I, Hallqvist J, Ljung R, Hammar N. Insulin-like growth factor binding protein-1 is a long-term predictor of heart failure in survivors of a first acute myocardial infarction and population controls. Int J Cardiol. 2010;138:50-55

18. Harrela M, Qiao Q, Koistinen R, Tuomilehto J, Nissinen A, Seppala M, Leinonen P. High serum insulin-like growth factor binding protein-1 is associated with increased cardiovascular mortality in elderly men. Horm Metab Res. 2002;34:144-149

19. Laughlin GA, Barrett-Connor E, Criqui MH, Kritz-Silverstein D. The prospective association of serum insulin-like growth factor I (IGF-I) and IGF-binding protein-1 levels with all-cause and cardiovascular disease mortality in older adults: the Rancho Bernardo Study. J Clin Endocrinol Metab. 2004;89:114-120

20. Kaplan RC, McGinn AP, Pollak MN, Kuller L, Strickler HD, Rohan TE, Xue X, Kritchevsky SB, Newman AB, Psaty BM. Total insulin-like growth factor 1 and insulin-like growth factor binding protein levels, functional status, and mortality in older adults. J Am Geriatr Soc. 2008;56:652-660

21. Hu D, Pawlikowska L, Kanaya A, Hsueh WC, Colbert L, Newman AB, Satterfield S, Rosen C, Cummings SR, Harris TB, Ziv E. Serum insulin-like growth factor-1 binding proteins 1 and 2 and mortality in older adults: the Health, Aging, and Body Composition Study. J Am Geriatr Soc. 2009;57:1213-1218

22. Yeap BB, Chubb SA, McCaul KA, Ho KK, Hankey GJ, Norman PE, Flicker L 2011 Associations of IGF1 and IGFBPs 1 and 3 with all-cause and cardiovascular mortality in older men: the Health In Men Study. Eur J Endocrinol 164: 715-723

23. Wolpin BM, Meyerhardt JA, Chan AT, et al. Insulin, the insulin-like growth factor axis, and mortality in patients with nonmetastatic colorectal cancer. J Clin Oncol. 2009)27:176-185

24. Wolpin BM, Michaud DS, Giovannucci EL, Schernhammer ES, Stampfer MJ, Manson JE, Cochrane BB, Rohan TE, Ma J, Pollak MN, Fuchs CS. Circulating insulin-like growth factor binding protein-1 and the risk of pancreatic cancer. Cancer Res. 2007;15;67(16):7923-8

25. Kalme T, Seppälä M, Qiao Q, et al. Sex hormone-binding globulin and insulin-like growth factor-binding protein-1 as indicators of metabolic syndrome, cardiovascular risk, and mortality in elderly men. J Clin Endocrinol Metab. 2005;90:1550-1556 
26. Wallander M, Norhammar A, Malmberg K, Ohrvik J, Rydén L, Brismar K. IGF binding protein 1 predicts cardiovascular morbidity and mortality in patients with acute myocardial infarction and type 2 diabetes. Diabetes Care 2007;30:2343-2348

27. Mesotten D, Delhanty PJ, Vanderhoydonc F, et al. Regulation of insulin-like growth factor binding protein-1 during protracted critical illness. J Clin Endocrinol Metab. 2002;87:5516-5523

28. Roth J, Whitford I, Dankner R, Szulc AL. How the immunoassay transformed Cpeptide from a duckling into a swan. Diabetologia 2012;55:865-869

29. Pyörälä M, Miettinen $H$, Laakso $M$, Pyörälä K. Plasma insulin and all-cause, cardiovascular, and noncardiovascular mortality: the 22-year follow-up results of the Helsinki Policemen Study. Diabetes Care 2000;8:1097-1102

30. Hu G, Tuomilehto J, Eliasson M, Feskens EJ, Pyörälä K. DECODE Insulin Study Group. Plasma insulin and cardiovascular mortality in non-diabetic European men and women: a meta-analysis of data from eleven prospective studies. Diabetologia 2004;47:1245-56

31. Ruige JB, Assendelft WJ, Dekker JM, Kostense PJ, Heine RJ, Bouter LM. Insulin and risk of cardiovascular disease: a meta-analysis. Circulation 1998;97:996-1001

32. Mohamed-Ali V, Gould MM, Gillies S, Goubet S, Yudkin JS, Haines AP. Association of proinsulin-like molecules with lipids and fibrinogen in non-diabetic subjects: evidence against a modulating role for insulin. Diabetologia 1995;38:1110-1116

33. Båvenholm P, Proudler A, Tornvall $P$, Godsland I, Landou C, de Faire U, Hamsten A. Insulin, intact and split proinsulin, and coronary artery disease in young men. Circulation 1995;92:1422-1429

34. Zethelius B, Byberg L, Hales CN, Lithell H, Berne Proinsulin is an independent predictor of coronary heart disease: Report from a 27-year follow-up study. Circulation 2002;105:2153-2158

35. Walraven I, van 't Riet E, Stehouwer CD, Polak BC, Moll AC, Dekker JM, Nijpels G. Fasting proinsulin levels are significantly associated with 20 year cancer mortality rates. The Hoorn Study. Diabetologia 2013;56(5):1148-54

36. Malaguarnera R, Sacco A, Voci C, Pandini G, Vigneri R, Belfiore A. Proinsulin binds with high affinity the insulin receptor isoform $\mathrm{A}$ and predominantly activates the mitogenic pathway. Endocrinology 2012;153(5):2152-63

37. Alehagen U, Ericsson A, Dahlström U. Are there any significant differences between females and males in the management of heart failure? Gender aspects of an elderly population with symptoms associated with heart failure. J Card Fail. 2009;15: 501-507

38. Karl J, Borgya A, Gallusser A, Huber E, Krueger K, Rollinger W \& Schenk J. Development of a novel, N-terminal-proBNP (NTproBNP) assay with a low detection limit. Scandinavian Journal of Clinical and Laboratory Investigation 1999; 230:177181.

39. Cockcroft DW, Gault MH. Prediction of creatinine clearance from serum creatinine. Nephron 1976;16(1):31-41 
40. Choy AM, Darbar D, Lang CC, Pringle TH, McNeill GP, Kennedy NS, Struthers AD. Detection of left ventricular dysfunction after acute myocardial infarction: comparison of clinical, echocardiographic, and neurohormonal methods. Br Heart J. 1994;72:1622

41. van Royen N, Jaffe CC, Krumholz HM, Johnson KM, Lynch PJ, Natale D, Atkinson P, Deman P, Wackers FJ. Comparison and reproducibility of visual echocardiographic and quantitative radionuclide left ventricular ejection fractions. Am J Cardiol. 1996; 77:843-850

42. Liese AD, Mayer-Davis EJ, Haffner SM. Development of the multiple metabolic syndrome: an epidemiologic perspective. Epidemiol Rev. 1998;20:157-172

43. Kalme T, Seppälä M, Qiao Q, Koistinen R, Nissinen A, Harrela M, Loukovaara M, Leinonen P, Tuomilehto J. Sex hormone-binding globulin and insulin-like growth factor-binding protein-1 as indicators of metabolic syndrome, cardiovascular risk, and mortality in elderly men. J Clin Endocrinol Metab. 2005;90:1550-1556

44. Heald AH, Cruickshank JK, Riste LK, Cade JE, Anderson S, Greenhalgh A, Sampayo J, Taylor W, Fraser W, White A, Gibson JM. Close relation of fasting insulin-like growth factor binding protein-1 (IGFBP-1) with glucose tolerance and cardiovascular risk in two populations. Diabetologia 2001;44:333-339

45. Undén AL, Elofsson S, Brismar K. Gender differences in the relation of insulin-like growth factor binding protein-1 to cardiovascular risk factors: a population-based study. Clin Endocrinol. 2005;63:94-102.

46. Alssema M, Dekker JM, Nijpels G, Stehouwer CD, Bouter LM, Heine RJ. Proinsulin concentration is an independent predictor of all-cause and cardiovascular mortality: an 11-year follow-up of the Hoorn Study. Diabetes Care 2005;28:860-865

47. Lindström TH, Arnqvist HJ, von Schenck HH. Effect of conventional and intensified insulin therapy on free-insulin profiles and glycemic control in NIDDM. Diabetes Care 1992;15:27-34

48. Mottillo S, Filion KB, Genest J, Joseph L, Pilote L, Poirier P, Rinfret S, Schiffrin EL, Eisenberg MJ. The metabolic syndrome and cardiovascular risk - a systematic review and meta-analysis. J Am Coll Cardiol. 2010;56:1113-1132

49. Galloway JA, Hooper SA, Spradlin CT, Howey DC, Frank BH, Bowsher RR, Anderson JH. Biosynthetic human proinsulin. Review of chemistry, in vitro and in vivo receptor binding, animal and human pharmacology studies, and clinical trial experience. Diabetes Care 1992;15:666-692 


\section{Tables}

Table 1a. Population baseline characteristics and cardio-metabolic variables presented as tertiles 1 to 3 of IGFBP-1.

\begin{tabular}{|c|c|c|c|c|}
\hline & & IGFBP-1 & & p value \\
\hline & tertile 1 & tertile 2 & tertile 3 & \\
\hline & $1.1-11.7 \mu \mathrm{g} / \mathrm{L}$ & $11.72-22.6 \mu \mathrm{g} / \mathrm{L}$ & $22.7-490.6 \mu \mathrm{g} / \mathrm{L}$ & \\
\hline & $(n=283)$ & $(n=284)$ & $(n=284)$ & \\
\hline \multicolumn{5}{|l|}{ Variable } \\
\hline Male, n (\%) & $137(33.0)$ & $136(32.8)$ & $142(34.2)$ & NS \\
\hline Female, n (\%) & $146(33.5)$ & $148(33.9)$ & $142(32.6)$ & NS \\
\hline Age, $($ mean $\pm \mathrm{SD})$, years & $72.0(3.2)$ & $73.0(3.5)$ & $73.9(3.4$ & $<0.001$ \\
\hline Current smokers, n (\%) & $27(34.6)$ & $17(21.8)$ & $34(43.6)$ & 0.045 \\
\hline \multicolumn{5}{|l|}{ Clinical History } \\
\hline Diabetes mellitus, n (\%) & $41(31.1)$ & $34(25.8)$ & $57(43.2)$ & 0.02 \\
\hline $\mathrm{CAD}, \mathrm{n}(\%)$ & $36(28.3)$ & $45(35.4)$ & $46(36.2)$ & NS \\
\hline EKG, n (\%) & $13(27.7)$ & $14(29.8)$ & $20(42.6)$ & NS \\
\hline $\mathrm{IHD}, \mathrm{n}(\%)$ & $44(28.0)$ & $56(35.7)$ & $57(36.3)$ & NS \\
\hline NYHA I, n (\%) & $175(33.7)$ & $182(35.1)$ & $162(31.2)$ & NS \\
\hline NYHA II, n (\%) & $83(31.2)$ & $87(32.7)$ & $96(36.1)$ & NS \\
\hline NYHA III, n (\%) & $25(39.7)$ & $15(22.7)$ & $26(39.4)$ & NS \\
\hline \multicolumn{5}{|l|}{ Clinical variables } \\
\hline $\mathrm{BMI}($ mean $\pm \mathrm{SD}), \mathrm{kg} / \mathrm{m} 2$ & $28.5(4.1)$ & $26.9(3.8)$ & $24.6(3.9)$ & $<0.001$ \\
\hline $\mathrm{EF}<40 \%, \mathrm{n}(\%)$ & $8(19.0)$ & $15(35.7)$ & $19(45.2)$ & NS \\
\hline \multicolumn{5}{|l|}{ Clinical examination } \\
\hline blood pressure systolic (mean $\pm \mathrm{SD}$ ), $\mathrm{mmHg}$ & $162.2(17.4)$ & $158.9(19.2)$ & $159.1(20.6)$ & NS \\
\hline blood pressure diastolic (mean $\pm \mathrm{SD}), \mathrm{mmHg}$ & $86.5(8.4)$ & $85.3(9.2)$ & $84.1(9.0)$ & 0.06 \\
\hline \multicolumn{5}{|l|}{ Laboratory analyses } \\
\hline $\mathrm{IGF}-1($ mean $\pm \mathrm{SD}), \mu \mathrm{g} / \mathrm{L}$ & $85.2(27.7)$ & $78.7(26.6)$ & $73.5(26.2)$ & $<0.001$ \\
\hline${ }^{10} \log$ proinsulin $($ mean $\pm S D), \mathrm{pmol} / \mathrm{L}$ & $0.95(0.40)$ & $0.93(0.33)$ & $0.83(0.35)$ & $<0.001$ \\
\hline${ }^{10} \log$ insulin $($ mean $\pm \mathrm{SD}), \mathrm{pmol} / \mathrm{L}$ & $1.76(0.29)$ & $1.65(0.29)$ & $1.57(0.36)$ & $<0.001$ \\
\hline blood glucose (mean $\pm \mathrm{SD}), \mathrm{mmol} / \mathrm{l}$ & $4.62(1.23)$ & $4.59(1.35)$ & $4.87(1.84)$ & 0.05 \\
\hline HOMA & $1.6(59.6)$ & $1.3(63.1)$ & $1.0(94.3)$ & NS \\
\hline cholesterol, mean (SD), mmol/L & $6.07(1.1)$ & $6.1(1.1)$ & $6.0(1.2)$ & NS \\
\hline triglycerides, mean (SD), mmol/L & $1.6(0.7)$ & $1.5(0.7)$ & $1.37(0.7)$ & $<0.001$ \\
\hline $\log$ NT-proBNP $($ mean \pm SD), $\mathrm{pmol} / \mathrm{L}$ & $2.02(0.39)$ & $2.11(0.44)$ & $2.29(0.48)$ & $<0.001$ \\
\hline $\mathrm{eGFR}<60 \mathrm{~mL} / \mathrm{min}, \mathrm{n}(\%)$ & $60(16.6)$ & $124(34.3)$ & $178(49.2)$ & $<0.001$ \\
\hline $\mathrm{Hb}$, mean $(\mathrm{SD}), \mathrm{g} / \mathrm{L}$ & $143.7(12.6)$ & $140.6(11.1)$ & $136.3(12.8)$ & $<0.001$ \\
\hline \multicolumn{5}{|l|}{ Treatment } \\
\hline ACE-inhibitor, n (\%) & $58(33.5)$ & $56(32.4)$ & $59(34.1)$ & NS \\
\hline$\beta$-blocker, n(\%) & $61(30.5)$ & $71(35.5)$ & $68(34.0)$ & NS \\
\hline Diuretc, $n(\%)$ & $79(32.9)$ & $78(32.5)$ & $83(34.6)$ & NS \\
\hline
\end{tabular}

Note: $\mathrm{ACE}=$ angiotensin-converting enzyme; $\mathrm{BMI}=$ body mass index; $\mathrm{BP}=$ blood pressure; $\mathrm{CAD}=$ coronary artery disease; $\mathrm{CRP}=\mathrm{C}$-reactive protein; IGFBP-1 = insulin-like factor binding protein-1; IQR = interquartile range; $\mathrm{ECG}=$ electrocardiogram indicative of IHD; EF=ejection fraction; estimated CG GFR $<60=$ estimated Cockcroft-Gault glomerular filtration ratio less than $60 \mathrm{~mL} / \mathrm{min}$; IHD= ischemic heart disease; HOMA = homeostatic model assessment NYHA = New York Heart Association functional class; EF = ejection fraction; $\mathrm{Hb}=$ hemoglobin; NTproBNP $=\mathrm{N}$-terminal proBNP. 
Table 1b. Post hoc analyses for those population baseline characteristics and cardio-metabolic variables which were significantly different when compared between tertiles 1 to 2 , and 1 to 3 of IGFBP.

\begin{tabular}{|l|l|l|l|}
\hline & & IGFBP-1 & \\
\hline age & tertile 1 vs 2 & tertile 1 vs 3 & tertile 2 vs 3 \\
\hline current smokers & $<0.001$ & $<0.001$ & 0.01 \\
\hline DM & $\mathrm{NS}$ & $\mathrm{NS}$ & $\mathrm{NS}$ \\
\hline BMI & $\mathrm{NS}$ & $\mathrm{NS}$ & $\mathrm{NS}$ \\
\hline blood glucose & $<0.001$ & $<0.001$ & $<0.001$ \\
\hline triglycerides & $\mathrm{NS}$ & $\mathrm{NS}$ & $\mathrm{NS}$ \\
\hline $\mathbf{1 0} \log$ insulin & $\mathrm{NS}$ & $<0.001$ & 0.03 \\
\hline $\mathbf{1 0} \log$ proins ulin & 0.001 & $<0.001$ & 0.009 \\
\hline $\mathbf{l o g}$ NT pro-BNP & $\mathrm{NS}$ & 0.001 & 0.005 \\
\hline eGFR $<\mathbf{6 0}$ & 0.03 & $<0.001$ & $<0.001$ \\
\hline Hb & $<0.001$ & $<0.001$ & $<0.001$ \\
\hline
\end{tabular}

Note: IGFBP-1 = insulin-like factor binding protein-1, DM=Diabetes Mellitus, BMI= Body Mass Index, eCG GFR $<60=$ estimated Cockcroft-Gault glomerular filtration ratio less than $60 \mathrm{~mL} / \mathrm{min}$, $\mathrm{Hb}=$ hemoglobin; NT-proBNP $=\mathrm{N}$-terminal proBNP, ${ }^{10} \log =\log 10$ transformed, vs $=$ versus . 
Table 2. Cardiovascular mortality and all-cause mortality in tertiles 1 to 3 of IGFBP-1, proinsulin, and insulin in the study population during eight years of follow-up.

\begin{tabular}{|l|l|c|c|c|}
\hline & & & IGFBP-1 & \\
\hline IGFBP-1 & CV mortality & $32(23.9 \%)$ & $40(29.9 \%)$ & $62(46.3 \%)$ \\
\hline & All causes mortality & $57(24.8 \%)$ & $71(30.9 \%)$ & $102(44.3 \%)$ \\
\hline proinsulin & CV mortality & $43(32.1 \%)$ & $30(22.4 \%)$ & $61(45.5 \%)$ \\
\hline & All causes mortality & $68(29.6 \%)$ & $60(26.1 \%)$ & $102(44.3 \%)$ \\
\hline ins ulin & CV mortality & $43(32.1 \%)$ & $37(27.6 \%)$ & $54(40.35 \%)$ \\
\hline & All causes mortality & $73(31.7 \%)$ & $63(27.4 \%)$ & $94(40.9 \%)$ \\
\hline NT-proBNP & CV mortality & $30(22.45)$ & $24(17.9 \%)$ & $80(59.7 \%)$ \\
\hline & All causes mortality & $57(24.8 \%)$ & $53(23.0 \%)$ & $120(52.2 \%)$ \\
\hline
\end{tabular}

Note: IGFBP-1 = insulin-like factor binding protein-1, CV mortality = cardiovascular mortality, NT-proBNP $=$ N-terminal proBNP

Table 3a. Univariate Cox proportional hazard regression analysis of prognostic power concerning all causes and cardiovascular mortality for the entire follow-up period for tertiles 2 to 1 and 3 to 1 of IGFBP-1, insulin, and proinsulin.

\begin{tabular}{|c|c|c|c|c|c|c|c|c|c|}
\hline \multicolumn{10}{|c|}{ All-cause mortality } \\
\hline & IGFBP-1 & & & insulin & & \multicolumn{3}{|c|}{ proinsulin } & \multirow[b]{2}{*}{$p$ value } \\
\hline & HR & $95 \% \mathrm{Cl}$ & p value & HR & $95 \% \mathrm{Cl}$ & p value & HR & $95 \% \mathrm{Cl}$ & \\
\hline tertile 1 & 1 & & & 1 & & & 1 & & \\
\hline tertile 2 & 1.2 & $0.9-1.7$ & 0.2 & 0.8 & $0.6-1.2$ & 0.3 & 0.8 & $0.6-1.1$ & 0.2 \\
\hline tertile 3 & 1.9 & $1.3-2.6$ & $<0.001$ & 1.2 & $0.9-1.6$ & 0.3 & 1.6 & $1.2-2.2$ & 0.003 \\
\hline \multicolumn{10}{|c|}{ Cardiovascular mortality } \\
\hline tertile 1 & 1 & & & 1 & & & 1 & & \\
\hline tertile 2 & 1.2 & $0.8-2.0$ & 0.4 & 0.8 & $0.5-1.3$ & 0.4 & 0.6 & $0.4-1.0$ & $<0.05$ \\
\hline tertile 3 & 2.0 & $1.3-3.1$ & 0.001 & 1.1 & $0.8-1.7$ & 0.5 & 1.5 & $1.0-2.2$ & 0.04 \\
\hline
\end{tabular}

Note: IGFBP-1 = insulin-like factor binding protein-1, CI = confidence interval, HR =hazard ratio. 


\section{Legend to figure:}

Figure 1. Kaplan-Meier analysis comparing all-cause mortality(a) and cardiovascular mortality during a follow-up period up to 12 years (b) for tertiles 1 to 3 of IGFBP-1, as well as analysis of cardiovascular mortality for tertiles 1 to 3 of proinsulin (c) and insulin (d).

a) All-cause mortality for IGFBP-1

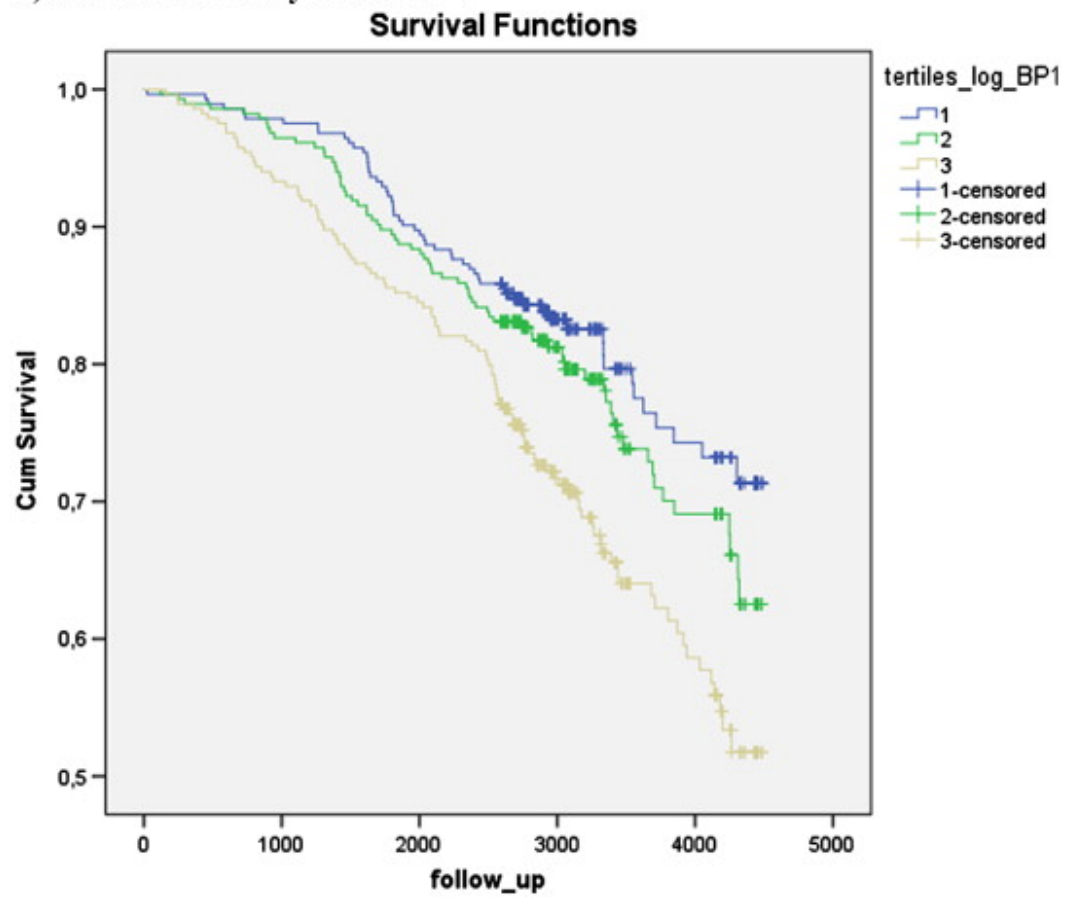

b) Cardiovascular mortality for IGFBP-1

Survival Functions

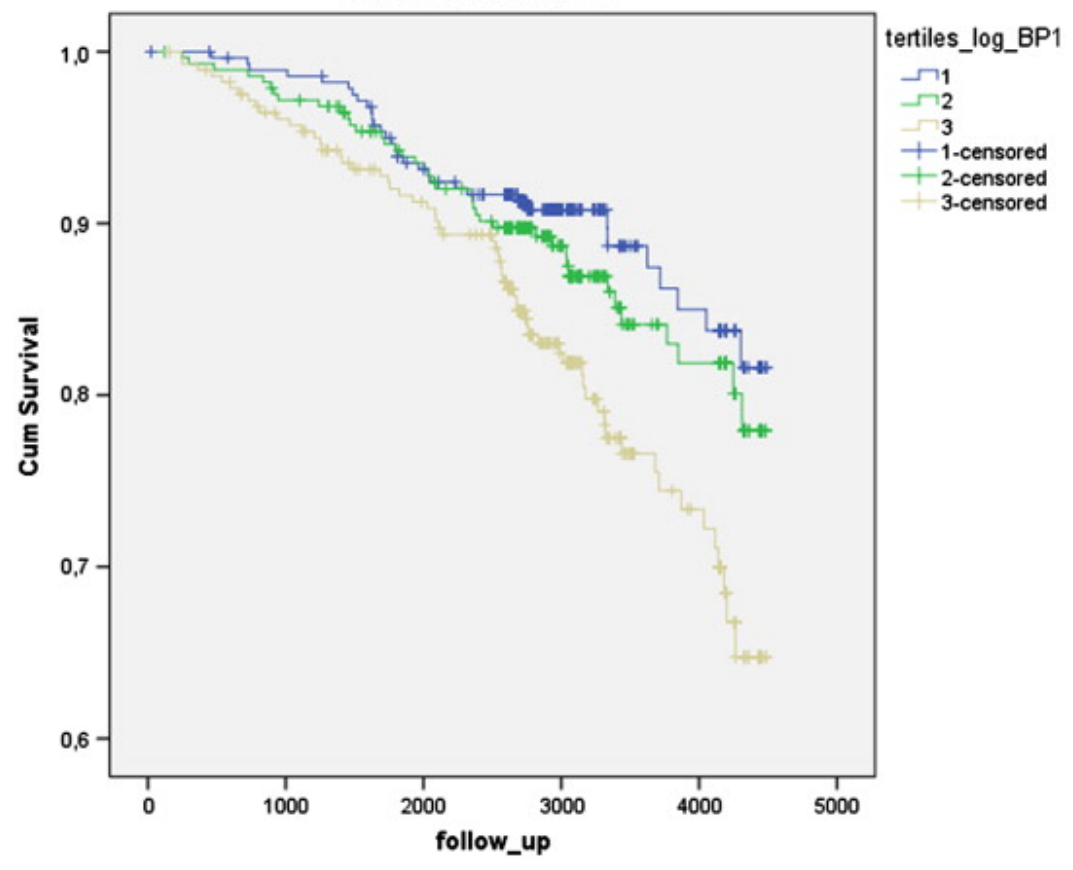


c) Cardiovascular mortality for proinsulin

Survival Functions

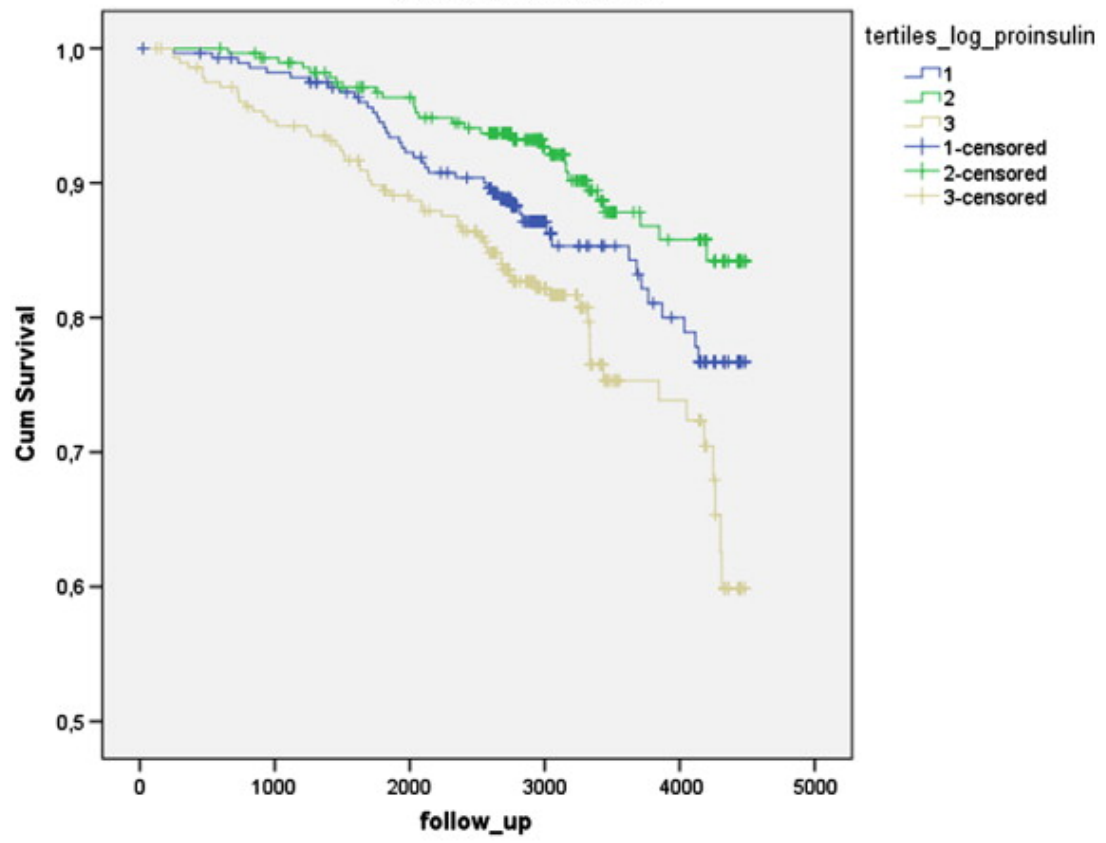

d) Cardiovascular mortality for insulin

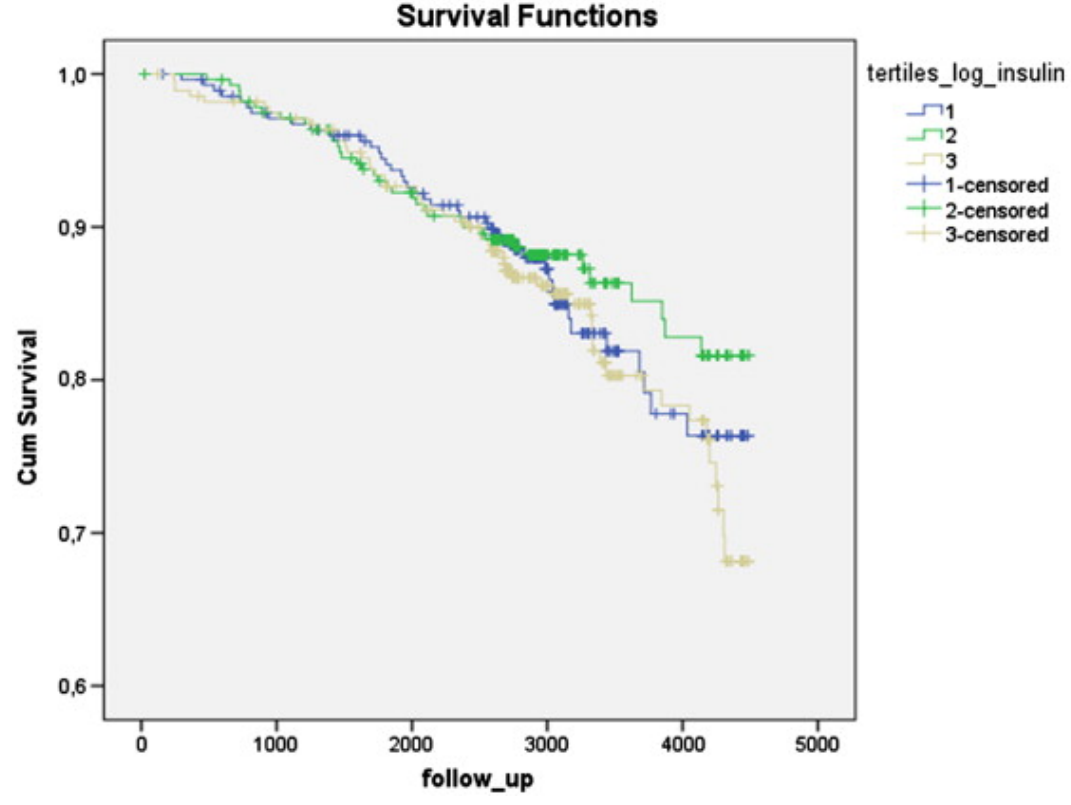

